Bryn Mawr College

Scholarship, Research, and Creative Work at Bryn Mawr College

2019

\title{
Tiananmen Square, Leipzig, and the "Chinese Solution": Revisiting the Wende from an Asian- German Perspective
}

Qinna Shen

Bryn Mawr College, qshen@brynmawr.edu

Let us know how access to this document benefits you.

Follow this and additional works at: https://repository.brynmawr.edu/german_pubs

Part of the German Language and Literature Commons

\section{Custom Citation}

Shen, Qinna. 2019. "Tiananmen Square, Leipzig, and the 'Chinese Solution': Revisiting the Wende from an Asian-German Perspective." German Studies Review 42.1: 37-56.

This paper is posted at Scholarship, Research, and Creative Work at Bryn Mawr College. https://repository.brynmawr.edu/german_pubs/18

For more information, please contact repository@brynmawr.edu. 
Tiananmen Square, Leipzig, and the "Chinese Solution": Revisiting the Wende from an Asian-German Perspective

Qinna Shen

\begin{abstract}
This article explores the transnational connection between China and the GDR in 1989 and views the student protests on Tiananmen Square in spring 1989 as a consequential precursor to German reunification. The SED's endorsement of the Chinese government's suppression and the East Germans' fear of a "Chinese solution” to looming domestic unrest aggravated the mass exodus in the summer and fall of 1989. Contrary to expectations, Leipzig, the center of protests in East Germany, did not become another Tiananmen on October 9. The military crackdown in Beijing ultimately served as a counterexample that helped to facilitate a peaceful revolution in East Germany.
\end{abstract}

The year 1989 was a watershed for both the People's Republic of China (PRC) and the German Democratic Republic (GDR), as each of the two Communist states faced widespread popular demonstrations that threatened to destabilize these nations. During the fall of 1989, the East German government's response to domestic unrest would echo the stance Beijing had taken toward student protesters in the spring, up until the last moment, when the GDR swerved from the path of violent repression followed by China. After the military crackdown in Beijing in June, ordinary Germans in the East and West alike condemned state violence against demonstrators. The East German government, 
however, was one of the few foreign governments - along with Cuba, Czechoslovakia, Romania, and North Korea—that endorsed the Chinese government's military actions. ${ }^{1}$ The vice chairman of the GDR state council, Egon Krenz, was the most senior Eastern European leader to visit Beijing for the PRC's fortieth anniversary on October 1,1989. ${ }^{2}$ The solidarity the SED (Socialist Unity Party) regime showed for the military crackdown caused a visceral reaction among many East German citizens and further alienated them from their own government. This was one of the reasons for the mass exodus from the GDR in the summer and fall of 1989, followed by large demonstrations in Leipzig and other East German cities. ${ }^{3}$

Ever since the Tiananmen incident on June 4, Eastern Europeans had used the phrase "die chinesische Lösung" (the Chinese solution) to refer to a Tiananmen-style crackdown against prodemocracy movements. From then on, the possibility of a "Chinese solution" hung like the sword of Damocles over the head of East Germans. ${ }^{4}$ The state leader and chairman of the National Defense Council, Erich Honecker, and the Stasi chief Erich Mielke did not exclude a "Chinese solution" in order to "nip hostile activities in the bud and prevent a mass basis from forming." The "Chinese solution" was on the brink of being carried out on October 9 in Leipzig, but the troops guarding the demonstrators retreated unexpectedly, paving the way for a peaceful revolution. In the end, Tiananmen functioned not as a model for repression, but as a cautionary tale, a bloodbath that neither Mikhail Gorbachev nor the majority of the East German politburo members, party officials, or citizens wanted to see repeated. Thus, I argue, the example of the "Chinese solution" actually helped to induce a peaceful revolution in East Germany. 
This study returns to that fateful year of 1989 after thirty years. It examines the divergent reactions toward the student movement in East and West Germany. It explores the connections between Tiananmen and the fall of the Berlin Wall, especially the role Gorbachev played as an eyewitness to protests in both China and the GDR. It reconstructs the events in Leipzig, on October 9 in particular, to demonstrate the impact of Tiananmen on East German strategy. It compares Tiananmen with Leipzig and analyzes the reasons for the different outcomes. Although much has been written on Tiananmen, as well as on German reunification, the connection between these two events has been largely overlooked. Wu'er Kaixi, the prominent Chinese student leader of Uyghur background, claimed that the popular movement in the GDR was, to some extent, inspired by the student demonstrations at Tiananmen. ${ }^{6}$ Ying-shih $\mathrm{Yu}$, a professor of Chinese studies, fairly assessed the connection between China and Eastern Europe: "It would be an exaggeration ... to say that what is happening in Eastern Europe would not have happened without Tiananmen Square. But what happened in Tiananmen Square had some bearing on what's happening in Eastern Europe today." "7ikewise, this essay argues that the student movement in China was not a precondition for German reunification, but rather a consequential precursor to it. The prodemocracy movement in China coincided with liberalization tendencies in the Soviet Bloc. The slaughter in Beijing and the subsequent isolation of the Chinese government served as a warning to Eastern European regimes. By integrating Tiananmen into the discourse about German reunification and the fall of Communism in Eastern Europe, the essay adds an Asian German perspective on the Wende. Whereas the Chinese government did everything to erase June 4 from public memory, this essay revisits that suppressed national trauma and conjoins it with the fall 
of the Berlin Wall five months later, an event that has ever since been remembered and celebrated both in Germany and abroad.

June Fourth and Gorbachev in Beijing and East Berlin The Chinese student protest is known as the June Fourth Movement because of the date on which the government used the military to end the demonstrations and clear out Tiananmen Square. But the movement, in fact, started several weeks earlier on April 16, 1989, when Beijing students marched spontaneously to mourn the death of Hu Yaobang, the former general secretary of the Chinese Communist Party (CCP), who was forced to resign for being too lenient toward prodemocracy student protests in 1986. When Hu died of a heart attack on April 15, students took to the streets to demand his rehabilitation as well as the freedom of the press and freedom of assembly. They also called for reforms within the party on issues such as corruption, nepotism, and official speculation (guandao), which caused rampant inflation in the late 1980s. While the pro-reform general secretary, Zhao Ziyang, was away on a state visit in North Korea, conservative leaders orchestrated hardline actions with occasional concessions. On April 26, the People's Daily (Renmin Ribao) published an editorial that labeled the protests "counterrevolutionary turmoil" manipulated by a small handful of people with ulterior motives, thus exasperating and alienating the students, who thereupon inveighed against the hardliners, especially Deng Xiaoping, who was in charge of the Central Military Commission, and the premier Li Peng, demanding the retraction of the editorial as well as official recognition of the movement as patriotic. ${ }^{8}$ 
From the very beginning, East and West German media reported events in China differently. Whereas West German media unanimously leaned toward the students, the East German media relayed the official language of the Xinhua (New China) News Agency and the People's Daily. On April 20, the East German state television broadcast, Aktuelle Kamera, reported: "Some people tried to incite unrest by giving demagogic speeches and shouting antigovernment slogans." ${ }^{9}$ On the following day, Aktuelle Kamera recommended a stern response to the protesters: "The actions of the disturbers have already exceeded the legally permissible limits. It is necessary to put an end to the unlawful actions through resolute measures." ${ }^{10}$ GDR print media, including the three major newspapers Neues Deutschland, Berliner Zeitung, and Neue Zeit, emphasized that the movement was essentially a planned conspiracy to undermine the leading role of the CCP and the socialist system, and that the Chinese government appealed to all parties and people to unite behind the CCP to fight public unrest and protect the hard-won political stability. ${ }^{11}$

It is worth emphasizing that Gorbachev made a state visit to China during the student hunger strike in May 1989. Thirty years had passed since the last official visit by Nikita Khrushchev in 1959. Gorbachev's trip would officially normalize the Sino-Soviet relationship and end the Sino-Soviet Split. On May 13, two days before Gorbachev arrived in Beijing, students started a hunger strike in Tiananmen Square to pressure the government to heed their demands. Students hailed Gorbachev as a champion of political reform in Communist countries, holding signs in Chinese, English, and Russian for the benefit of the foreign media that had come to report on the epoch-making summit. It was highly inconvenient and embarrassing for Chinese officials that the capital should be in 
"turmoil" when the country was preparing to welcome an important foreign leader and Beijing would be in the international media spotlight. The Chinese students were eager to greet Gorbachev in person at Tiananmen Square during the scheduled welcome ceremony. However, since the square brimmed over with students and citizens, the ceremony was extemporaneously relocated to the airport. Officials made a series of further changes to keep Gorbachev as far away from the crowds as possible. A visit to the Forbidden City next to the square was canceled. Gorbachev would no longer place a wreath in front of the Monument to the People's Heroes, which had become the rally headquarters on the square. He was ushered into the Great Hall of the People through a back door to give his speech and meet with Chinese leaders. He had to be driven by a back road to his guesthouse when students blocked the planned route, which had been decorated with Soviet and Chinese flags. ${ }^{12}$

Despite the efforts by officials to keep students at bay, unplanned encounters with young demonstrators nonetheless took place on the way back from Gorbachev's visit to the Great Wall and "made an enormous, even somewhat unexpected, impression on [him]." He wrote, "To be frank, in Moscow we had not imagined the scale of these demonstrations. ${ }^{" 13}$ As an outsider and a reformer himself, he viewed the young protesters sympathetically. At a press conference, he suggested that he understood the students' desire for democracy and individual rights. ${ }^{14}$ According to the New York Times, Gorbachev cautiously praised the students, repeatedly declared that economic change was impossible without political reform, and said, "I am convinced that we are participating in a very serious turning point in the development of world socialism." 15 This potentially signaled a green light to prodemocracy forces in the GDR. 
The tension and unrest that Gorbachev witnessed in Beijing and Shanghai in May erupted in East Berlin in October, when he was invited to attend the fortieth anniversary of the founding of the GDR. The repetition of this experience confirmed to him yet again that disillusion was widespread within Communist regimes. In Beijing, he had assuaged the Chinese leaders by remarking that change cannot be accomplished overnight as some "hotheads" might wish. ${ }^{16}$ The situation was drastically different in East Germany, a client state of the Soviet Union. Here Gorbachev, expressing his disappointment with Honecker's unwillingness to reform East Germany, said "Life punishes those who come too late"17 and spurred his East German colleagues to "act" ("Handelt!"18). He would never have spoken these words to his Chinese counterparts. He came to China to mend relationships, and thus the stance he took toward Chinese leaders was conciliatory and emphasized cooperation, rather than showing condescension or a reprimanding attitude as he would later assume toward GDR leaders.

While Gorbachev's reform policies were instrumental in the eventual downfall of Communist regimes in Eastern Europe, the student movement in China also occurred under the auspices of perestroika and glasnost. Zhao Ziyang acknowledged to Gorbachev the impact his perestroika had on China: "[Your political reform] has evoked special interest among the intelligentsia, which has demanded that China learn from you and emulate your experience."19 Gorbachev's visit unintentionally increased the scale of the student movement. On the eve of his visit, students started fasting, which struck a chord with the population at large and forced the hardliners to concede, albeit temporarily. On May 17 and 18, over a million people demonstrated in the center of Beijing. Workers, employees, entrepreneurs, intellectuals, and ordinary citizens joined the demonstrations, 
as well as representatives of state-controlled organs such as the People's Daily and the China Central Television Station (CCTV) and members of the department of justice, the general logistics department of the PLA (People's Liberation Army), public security forces, the propaganda department, and the foreign ministry. ${ }^{20}$ Medical personnel and ambulances were present to help the hunger strikers. Zhao Ziyang and his ally in the Politburo, Hu Qili, also encouraged media coverage of the student movement, and the People's Daily and other newspapers expressed much sympathy for the students. ${ }^{21}$ It seemed that the tide was changing. The East German media, however, did not reproduce this sympathetic tone, apparently to avoid contradicting its earlier reports or encouraging similar sentiments in the GDR. West German media, on the other hand, portrayed the student movement as the greatest political challenge the CCP had ever faced.

On May 20, hardly two days after Gorbachev left, the Chinese government officially announced martial law in eight districts of Beijing. Neues Deutschland reported Li Peng's justification for using force. ${ }^{22}$ Referring to the imposition of martial law, the West German magazine Der Spiegel (May 22) evoked the 1953 Worker's Rebellion in East Berlin that was crushed by Soviet tanks: "It was like on June 17, 1953 in East Berlin, only tanks were not yet in sight." ${ }^{23}$ Neues Deutschland, in contrast, claimed on May 24 that Western media reports about the entry of army units into the center of Beijing and serious clashes in Beijing and other parts of the country were exaggerated ("aufgebauschte Berichte"). ${ }^{24}$ Up until June 4, East German news repeatedly suggested that public order had been largely restored in Beijing and students had returned to campus, and that political leadership in China remained unchanged. 
East German Reactions to Tiananmen, Leipzig, and the "Chinese Solution"

On June 6, Gorbachev and the USSR Congress of People's Deputies expressed regret about what had happened in Beijing and sympathy for the victims, but adopted a policy of noninterference. ${ }^{25}$ The East German government diverged from Gorbachev's position and explicitly endorsed the repression. On June 5, Neues Deutschland defended the crackdown by publishing an editorial entitled "Volksbefreiungsarmee Chinas schlug konterrevolutionären Aufruhr nieder," which used impersonal, bureaucratic language to minimize the brutality of the suppression: "There were deaths and injuries" ("Es habe Tote und Verletzte gegeben"). The editorial also stated preposterously that the Chinese government measure "meets with the agreement of the masses and the students" ("Das finde die Zustimmung der Massen und der Studenten"). Further articles in East German media presented the Chinese government's justifications for its military actions and its praise for soldiers who had sacrificed themselves for the country. On June 7, Neues Deutschland published what the speaker of the state council, Yuan Mu, had stated on CCTV the day before about the number of casualties:

It is still too early to give the exact numbers of the dead and injured, but he could give some provisional information. Yuan Mu said that more than five thousand military personnel were injured. The injured from the civilian population, among them rioters and bystanders, number over two thousand. He could likewise only make a rough estimate about the number of the dead. The number of the dead, including members of the army, was close to three hundred. Four hundred soldiers 
were still missing. There is not a single trace of them. With some degree of precision, he could report that twenty-three students had died during the riot. ${ }^{26}$

The official Chinese declarations tended to emphasize and exaggerate the loss of the soldiers while minimizing and censoring information about student and civilian casualties. Whereas the actual number of civilian casualties is still unknown due to government censorship, Timothy Brook concluded on the basis of hospital statistics that the Red Cross figure of 2,600 was the best estimate of the number of people killed, and that at least twice that many were wounded. ${ }^{27}$

The senior East German leader, Egon Krenz, sent a message to Chinese leaders, congratulating them on their firmness. ${ }^{28} \mathrm{He}$ told the press during a visit to the Saarland in West Germany: "When evaluating events in the People's Republic of China one cannot depend on the horrific portrayals in the West German media. One has to rely on the real events and the explanations of the Chinese party and government leadership. It is made very clear there that the peaceful demonstrations of the students have been exploited as a counterrevolutionary coup in the PRC." ${ }^{29}$ The East German Volkskammer voted in support of the crackdown on the Chinese student movement. ${ }^{30}$ West German politicians condemned the GDR's "outrageous" ("unverschämte") approval of the measures taken by the Chinese government with the intention to "intimidate its own population." ${ }^{31}$ The GDR government also took measures to prevent open display of solidarity by its citizens with China's democracy movement. According to Walter Süß, Erich Mielke instructed leaders of secret police units that "any kind of provocative-demonstrative acts against the PRC, especially its embassy in the GDR," and the dissemination of "inflammatory 
speeches [Hetzschriften] against the politics of the PRC" were forbidden. State security and police disbanded small protests and temporarily arrested participants. Nonetheless, owing to the church's political immunity, over a thousand people gathered in Pastor Eppelmann's Samaritan Church in East Berlin on June 28 to commemorate the victims of June $4 .^{32}$

By endorsing the move made by the Chinese government, the SED sought to ensure that the former would show support for the GDR if it had to resort to similar measures to maintain power. The SED could no longer rely on Soviet tanks, as Gorbachev made very clear through his position toward Poland and Hungary. ${ }^{33}$ China, however, as James Miles points out, found itself isolated after June 4 and wanted to show its people that it had supporters, even if those supporters were themselves "international pariahs" such as East Germany, whose seventy-seven-year-old leader Erich Honecker was "more in the mold of China's gerontocracy." ${ }^{34}$ Over the summer, officials from both countries engaged in frequent high-level visits and the bilateral relationship between the two countries rose to its highest peak since Honecker's state visit to China in 1986. Already on July 1, a SED delegation under the leadership of Hans Modrow visited Beijing and was received by Politburo member Wu Xueqian. Another delegation under Minister Walter Halbritter visited Beijing and was welcomed by Vice Premier Yao Yilin. Günter Schabowski visited China in mid-July and met with the new general secretary, Jiang Zemin, and other high-level politicians. During every trip, the Chinese officials thanked their East German colleagues for their support in June, and the latter continued to endorse the policies of the Chinese government. ${ }^{35}$ 
Ordinary citizens in East Germany were, however, enraged at their government's emphatic solidarity with the Chinese government on the military crackdown. The GDR's support of China increased their fears that their own government might adopt the "Chinese solution" in the face of looming domestic unrest. Many East Germans, similar to West Germans, perceived the Chinese government as a corrupt authoritarian regime. However, they may not have seen the SED in quite the same light. When the SED sided with the Chinese government, it dawned on many that the SED itself was no better than a dictatorship. Along the same lines, Karsten Timmer observes that the SED's endorsement of China's suppression of a prodemocracy movement made many East German citizens draw a parallel between Beijing's policies and the lack of democratic freedom in the GDR. Very importantly, Timmer points out that the GDR's justification of the Beijing massacre belied its self-proclamation as a "peace state" ("Friedensstaat"). ${ }^{36}$ Thus many abandoned the GDR before things could get worse by crossing the Austrian-Hungarian border, which the Hungarian government opened partially on May 2, 1989, and completely on September 11, 1989. ${ }^{37}$

Leipzig established itself as the heart of protest in the fall of 1989 in East Germany, and October 9 would go down in history as the turning point in the "revolution from below" in the GDR. Before October 9, state violence was employed frequently in response to acts of civil disobedience. On Mondays during the Leipzig spring fairs in March 1989, about a hundred people who applied for exit visas assembled in the inner city of Leipzig where they carried placards to draw attention to their rejected or unprocessed applications. The police and security forces manhandled them brutally and arrested some of them. Already in June, demonstrations following peace prayers were 
occurring on a small scale in Leipzig. ${ }^{38}$ Also in June, opposition groups in the city organized a music festival in the pedestrian zone that was forcibly dissolved by security forces. On September 4, a joint demonstration held by both the visa protesters and opposition groups during the Leipzig fall fairs was violently dispersed by the secret police. On September 25, more than 5,000 people marched after the peace prayer at the Nikolaikirche. This was the first of the famous Monday demonstrations, and the number of demonstrators skyrocketed on the following Mondays in Leipzig. ${ }^{39}$

The protests spiked as the PRC and the GDR were each preparing for the fortieth anniversary of their founding, on October 1 and October 7, 1949, respectively. From September 25 to October 2, Egon Krenz headed a delegation that traveled to China for its anniversary celebration. He met with Deng Xiaoping, Jiang Zemin, Politburo member Qiao Shi, and other high-ranking officials. He placed a wreath in front of the Monument to the People's Heroes on Tiananmen Square, something that Gorbachev was not able to do, and stood on the VIP stand on Tiananmen, the Gate of Heavenly Peace, overlooking festivities in the square. ${ }^{40} \mathrm{He}$ also visited the provinces of Sichuan and Zhejiang. All the meetings demonstrated China's appreciation of "the timely and open solidarity of the GDR with the PRC" with respect to the crisis in June and confirmed that both countries stood fast in their support of peace and socialism. Both countries had to resist imperialist attempts to foster "peaceful evolution" ("friedlichen Wandel") and ideological infiltration. ${ }^{41}$ Reports in Neues Deutschland during Krenz's visit often implicitly underlined the importance of suppressing the "counterrevolutionary turmoil" in Beijing. ${ }^{42}$ All of this Chinese rhetoric assumed an increasing significance for domestic politics, raising the likelihood of a "Chinese solution" to the intensifying "riots." Official GDR 
rhetoric sounded very similar, labeling demonstrations at home "counterrevolution" and the demonstrators "rowdies," "ringleaders," and "enemies of the state."

When the GDR in turn celebrated its fortieth anniversary on October 7, China sent the deputy prime minister and hardline Politburo member Yao Yilin to attend the ceremony. During their meeting on October 9, the day of the showdown in Leipzig, Honecker said to Yao that there was "a fundamental lesson from the counterrevolutionary turmoil in Beijing and the present defamation campaign against the GDR and other socialist states, namely, to abide undeterred by the basic values of socialism and at the same time to continue to perfect the socialist society." ${ }^{43}$ Honecker was occupied by this meeting so that he did not get the emergency call from Leipzig on the decisive evening of October 9. Timmer suggests that the only person who would have insisted on a shoot-tokill policy would have been Honecker, but "it is an irony of history that Honecker cannot be reached: He is receiving a Chinese delegation, which created circumstances that prevented a Chinese solution in Leipzig." ${ }^{.44}$

However, before the fateful evening of October 9, the "sword of Damocles" could have fallen in East Germany at any time. On September 26, Honecker, extremely worried about protests in the capital of East Berlin, had signed a nebulous secret order ("Geheimbefehl" Nr. 8/89) to the district police in East Berlin that stopped just short of explicit shoot-to-kill language. ${ }^{45}$ At a meeting on September 27, the secretariat of the SED district leadership of Leipzig decided that "positions and personal opinions have to be organized among the collectives of the combat groups, where fighters should publicly profess to develop a high readiness, to defend the homeland (Heimat) with weapons against domestic and foreign enemies." ${ }^{, 46}$ On October 3, Mielke warned his regional 
commanders that the situation had become explosive: "Now we have to act, otherwise socialism goes down the drain. We now need consistency and relentlessness." ${ }^{\circ 7}$ On October 4 and 5, a fierce street fight took place between would-be emigrants and police forces at Dresden's train station. ${ }^{48}$

On October 5, Mielke ordered via a special priority telegram that "hostile and negative activities must be resolutely prohibited by all means. . . . Do not allow any surprises!"49 On October 6, the day before Gorbachev's arrival, one thousand protesters were arrested in various cities and security forces were instructed to prepare for "offensive measures" to stop demonstrators "by any means." Volkszeitung published a much-cited public statement by Günther Lutz, the commander of the local factory militia "Hans Geiffert," with the headline "State Subversion No Longer Tolerated": "We are ready and resolute to effectively protect what we have accomplished with our hands, in order to finally prevent these counterrevolutionary actions. If necessary, with weapons in hand!"51 Christoph Wielepp comments that this rallying cry called to mind Tiananmen, the Square of Heavenly Peace. But he suggests that the threat backfired because it unexpectedly mobilized people who refused to be treated in such a manner. ${ }^{52}$ Timmer also notes that "in the eyes of the people, the ordering of a Chinese solution presented the final and fundamental proof of the cynicism of the SED top leadership." ${ }^{, 53}$

Per the secret order 8/89, the Ministries of State Security, Interior, and National Defense were authorized to suppress all protests during the celebrations of October 6-8. Yet, on October 7, demonstrations erupted in the capital, as well as in the rest of the country - in Leipzig, Dresden, Plauen, Karl-Marx-Stadt, Halle, Erfurt, Rostock, 
Magdeburg, and Potsdam, among other cities. The exceedingly brutal police deployments targeted peaceful demonstrators; hundreds of people were injured that night and about 3,500 people were arrested.${ }^{54}$ On October 8 , Honecker sent a telex to Leipzig and put the acting first secretary of the SED local chapter, Helmut Hackenberg, in charge, with the instruction: "the district leadership should stop the riot at the outset." ${ }^{55}$ In anticipation of the Monday demonstration on October 9, officials and commanders emboldened the troops: "Today we have to put an end to the counterrevolution in Leipzig once and for all. ... Comrades, today class struggle begins. The situation is similar to June 17, 1953. Now it will be decided: them or us. Be class-vigilant [klassenwachsam]. If the club does not suffice, use your guns. ${ }^{956}$ Stasi lieutenant-general Manfred Hummitzsch had previously ordered that "hostile and negative activities must be curbed resolutely and with all means.. ${ }^{, 57}$

Hence, on October 9, the tense confrontation reached a tipping point and everyone was fearful of bloodshed. Shops and offices had closed by noon, and a great number of heavily armed troops were patrolling the city. Despite fear of a "Chinese solution," 70,000 people came out for the march after the traditional peace prayers. A petition for nonviolence drafted by three local SED functionaries and three local eminences including Kurt Masur, the music director of the Gewandhaus Orchestra, was read in four churches to great effect. Opposition groups in Leipzig, now joined by the New Forum (Neues Forum), the first independent political movement in the GDR, also issued an appeal to demonstrators to refrain from violence, and they nervously negotiated with moderate local party officials to press for a change of orders from East Berlin. ${ }^{58}$ 
Tiananmen Square was repeatedly evoked in the fall demonstrations. One of the signs demonstrators held up in front of the Nikolaikirche on October 9 read, "Egon Krenz, Mach Dir kein’ Lenz! China, Wahl, Polizeieinsatz-vergessen wir nicht!” (Egon Krenz, do not rest easy. We will never forget China, election, and police action). ${ }^{59}$ The slogan is a muted threat reminding Krenz that he should not get too comfortable because people will not forget his missteps: his support for China's military crackdown, his election commission that falsified the results of local elections on May 7, 1989, and the deployment of police to suppress domestic protests. A similar protest banner read “China-Kommunalwahlen—Krenz" (China—communal elections—Krenz). ${ }^{60} \mathrm{~A}$ ubiquitous slogan during the demonstrations was "Keine Gewalt" (No violence), and the allusion to the recent bloodshed in Beijing was too tangible to ignore. Another sign bluntly stated, "Krenz, mach Schluss mit den Mördern von Peking” (Krenz, stop dealing with the Beijing murderers!) (Figure 1). 


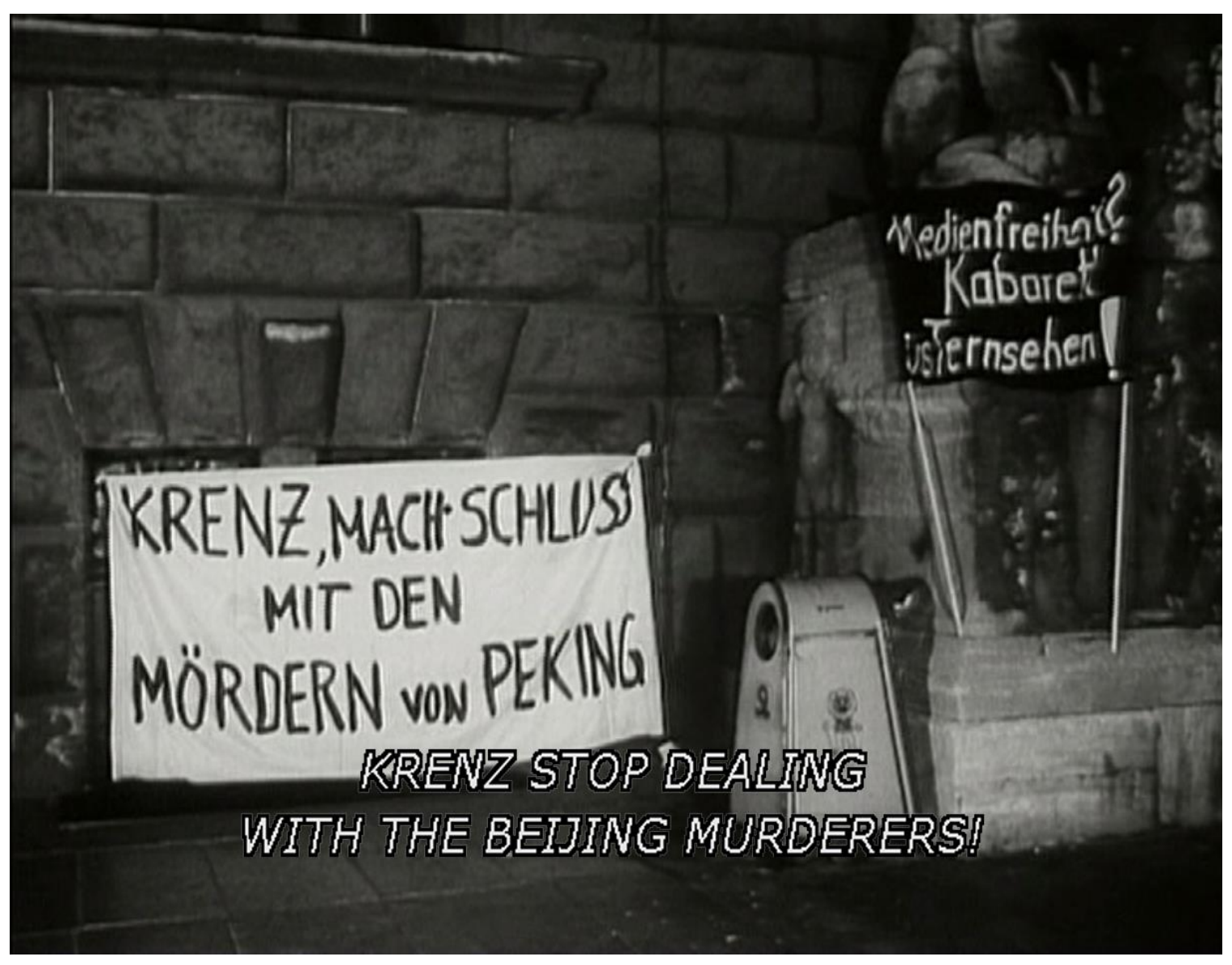

Fig. 1: Leipzig im Herbst (Leipzig in the Fall, dir. Gerd Kroske and Andreas Voigt, 1991, 06:46) ODEFA-Stiftung/P. Martins.

Laurence McFalls conducted survey interviews with demonstrators and observed the impact of Tiananmen:

Respondents who participated in the early, dangerous demonstrations spoke of fear, of anticipation of failure, and even of the futility of their action. Virtually none, moreover, mentioned the success of reform efforts in Hungary and Poland as an incentive or as evidence that repression was unlikely. Most expected a "Chinese solution" since the SED had praised the restoration of order in Tiananmen Square in June $1989 .{ }^{61}$ 
The situation on October 9 was unpredictable. However, the hardliners in Leipzig got "cold feet" in the final hours. ${ }^{62}$ The peace prayer services started at 17:00. At 17:15, Hackenberg called Stasi lieutenant-general Hummitzsch and ordered: “Don’t do anything as long as we can.” Hummitzsch advised him to call the SED Central Committee. Hackenberg could not reach Honecker because, ironically, the latter was meeting with the Chinese delegation. ${ }^{63}$ Then, shortly before 18:30, Hackenberg spoke with Krenz who, however, said he would call back after consulting with his ministers. In the meantime, Hackenberg gave the command to not "take any active action against demonstrators" for the time being, and ordered the officers to only defend themselves against attacks ("Eigensicherung"). ${ }^{64}$ Krenz did not call back until around 19:15; at this point the demonstration had almost surrounded the ring road and there had already been a tense moment in front of the Leipzig main train station around 19:00 when the massive assemblage of troops was tasked with ending the march. ${ }^{65}$ Demonstrators shouted "Kein neues China" (Not another China) at the sight of armed troops. ${ }^{66}$ But to everyone's relief, the protestors were allowed to file past the station without being mowed down. In fact, the army, police units, and factory militias all retreated out of sight, or as Albrecht Döhnert and Paulus Rummel summed it up, “The power of the state withdrew, and the consistently peaceful demonstrators were spared the fate of a 'Heavenly Peace.",67 Consequently, October 9, 1989 did not become another June 4, and Leipzig did not go down in history as another Tiananmen; instead it became a "city of heroes" ("Heldenstadt") in the words of Christoph Hein. ${ }^{68}$ While June 4 ended the prodemocracy movement in China, October 9 marked a new beginning in East Germany’s peaceful 
revolution, because, as Wielepp observes, "After October 9 demonstrations expanded, and the danger of a 'Chinese solution' dwindled more and more." ${ }^{.69}$ Likewise, Christoph Nonn remarks that on October 9 the state power gave up its hitherto pursued course of violence and the "Chinese solution" faded as an option for the future of the GDR. ${ }^{70}$

A war of words followed as various parties vied for credit for the peaceful outcome on October 9. David Friedheim debunks “Krenz's claim to have single-handedly averted the possibility of a bloody 'Chinese solution."'"71 Friedheim argues that more important than Krenz's belated intervention was the local initiative by Kurt Masur, the Lutheran Church, regional SED leaders, intelligentsia, and other state employees who had lost faith in the regime's right to use force. ${ }^{72}$ Timmer states two main reasons for the peaceful outcome: the sheer number of demonstrators-far more than the troops were prepared to handle — and the restraint of the demonstrators. Despite the presence of 70,000 protesters, not a single stone was thrown, not a single shop window was broken, and not a single policeman was attacked. Strict adherence to nonviolence was a tactic to ward off violent repression; it was also part of the well-established protest culture. ${ }^{73}$

The danger was, however, not immediately over after October 9 . Not until October 13 did Honecker sign Order 9/89, in which he commanded that "the use of firearms in connection with possible demonstrations is principally forbidden. ${ }^{" 74}$ With that, according to Peter Przybylski, "the Chinese answer to the challenges of the people's movement seemed finally off the table." ${ }^{.75}$ On October 18, Krenz replaced Honecker and initiated many reform policies, but his government was unable to win back trust from the people despite conciliatory measures catering to public demands. Some placards reminded him of his support for the Tiananmen crackdown: "Krenz Xiaoping, no 
thanks."76 In interviews, the later deposed Honecker denied that a Chinese solution had ever been considered by the SED ("Die chinesische Lösung hat trotz aller gegenteiligen Behauptungen bei uns nie gestanden."). When asked about the violent dispersion of the Monday demonstration in Leipzig on October 9, Honecker replied that a violent dispersion had not been planned at all, but if the demonstrators had stormed or set fire to any building, the police would of course have intervened to restore law and order; since the police were not attacked, there was no need to interfere. ${ }^{77}$

Unsurprisingly, the Chinese reports of the dramatic changes in East Germany were as sparing, reluctant, belated, selective, and sometimes as untrue as East German reports of Chinese protests in the spring of $1989 .{ }^{78}$ Chinese media reported the celebration of the GDR's fortieth anniversary without mentioning the antigovernment demonstrations. ${ }^{79}$ On November 10 , the day after the Berlin Wall opened, there was no mention at all of the historic event in Chinese media, although West German Chancellor Helmut Kohl's trip to Poland was reported. Chinese news articles confined themselves to reporting excerpts from Krenz's speeches about the necessity of reforming the party. ${ }^{80}$ According to the secret memoir of the purged Zhao Ziyang, the fall of Communism in Eastern Europe only confirmed to the Chinese hardliners that their "firm" response to the demonstrations in June was justified: "The subsequent collapse of the Soviet Union and the Eastern Bloc apparently hardens attitudes among Beijing's leaders, who conclude that hanging tightly to power is the key to the Communist Party's survival. The violent response to Tiananmen, they will argue, has been right all along." ${ }^{\prime 1}$ In the same vein, Tony Saich notes how CCP leaders "congratulate[d] themselves on avoiding the fate of their Romanian friend Ceausescu and the 'socialist traitor,' Gorbachev." 82 They also 
avoided the fate of the East German leaders, who were deposed, tried, and even imprisoned. James Miles likewise asserts that the chaos in the former Communist countries in Eastern Europe reassured Chinese leaders that their decision to take a tough line on dissent was correct. ${ }^{83}$

What Led to Different Outcomes in China and the GDR?

As demonstrated above, developments in the GDR and China in 1989 were intricately intertwined, but sharply diverging in their outcomes. The prodemocracy movements in both countries followed a similar course: protesters called for democracy and freedom and were encouraged by the momentum they achieved at home as well as by the example of Gorbachev's reforms, which their own governments rejected. But there are some important differences between the two movements that can help to explain the different outcomes.

First, the divergence between the two movements can be traced back to historical differences between the Communist revolutions in the Chinese and Soviet spheres. The $\mathrm{CCP}$ came to power as the result of an indigenous Communist revolution. Deng had experienced the Long March, civil wars, and the radical political campaigns under Mao that culminated in the Cultural Revolution. His own dramatic political career compelled him to do everything he could to keep himself in power. For Deng, the military crackdown was necessary to quell nationwide unrest, and the death of protesters was a small price to pay to preserve the country's stability and to safeguard the achievements his economic reforms had made possible. Already on April 25, Deng told Li Peng and Yang Shangkun that "we must do our best to avoid bloodshed, but we must foresee that it 
might be impossibility $[$ sic $]$ to completely avoid it. ${ }^{\prime 84}$ Deng and other party veterans (including Chen Yun and Li Xiannian) sided with hardliners in the Politburo who had favored implementing harsh measures as soon as the protests began. Zhao Ziyang's secret memoir suggests that the hardliners squandered and sabotaged opportunities for a peaceful, political solution to the unrest.

In contrast, state socialism had been imposed on Eastern European countries by the Soviet Union. ${ }^{85}$ The years 1953,1956 , and 1968 were marked by Soviet military suppression of democratic protests in the GDR, Hungary, and Czechoslovakia, respectively. Then, in 1981, after the Solidarity trade union was founded in Poland, the Polish government declared martial law, fearing that the Soviets would intervene. Given the earlier history of the Soviet Union's relations with its satellite states, Gorbachev's tolerance of democratizing tendencies in these countries was a striking departure from the Brezhnev Doctrine. Daniel Chirot has argued that sometime in 1988 Gorbachev decided that it was necessary to forestall a looming disaster threatened by political and social disintegration within the Soviet Union and the "moral rot" of Communism in Eastern Europe ${ }^{86}$ Thus on June 4, 1989-by coincidence, the very date of the Tiananmen incident - Gorbachev refused to employ military force when Poland held free elections. In the fall of 1989, almost half a million Soviet troops were still stationed in East Germany. However, Gorbachev had expressly given orders for the Soviet troops in East Berlin to remain in their barracks during the GDR's anniversary celebration. ${ }^{87}$ Consequently, the deployment of Soviet tanks in East Berlin during the Workers' Rebellion on June 17, 1953 was not repeated in 1989. Lack of support from Gorbachev 
was in the end a critically important factor that led the GDR to drop the "Chinese solution."

Second, the two movements differed in demographics, organization, and alliances (or lack thereof). The demonstrations in China were initiated by passionate, idealistic college students, as had been the case with the May Fourth movement in the early twentieth century. ${ }^{88}$ But the 1989 movement was more or less confined to the universities: Chinese workers, entrepreneurs, and intellectuals did not form viable alliances with students or consistent opposition groups, and therefore the movement was limited and vulnerable. Although on numerous occasions, especially after the hunger strike began, workers participated in demonstrations and students welcomed them, the movement initially avoided involving peasants, workers, and entrepreneurs due to elitism of students and urban intellectuals. ${ }^{89}$ Lawrence R. Sullivan also charts the distrust and animosity that have traditionally divided intellectuals and students from workers and city residents. $^{90}$

Besides elitism, Tony Saich points out a practical reason for the students' reluctance to include other groups: they did not want the government to use such alliances as an excuse to nip the movement in the bud. ${ }^{91}$ There are other important reasons why workers did not become a steady force in the movement, including the government's deterrent measures, its use of the work unit (danwei) as an instrument of political control, ${ }^{92}$ and the fact that workers' standard of living, relatively speaking, had improved since Deng's economic reforms. But in the aftermath of June Fourth it was the workers and other nonstudents who bore the brunt of the punishment, whereas no student executions were reported. ${ }^{93}$ 
Not only did Chinese students fail to form strong alliances with workers, the movement was also plagued by infighting, factionalism, and lack of coordination among student groups. Although the movement called for democracy, the movement itself was fraught with undemocratic procedures and the majority often had to obey the minority. ${ }^{94}$ Student leaders were particularly divided on whether to evacuate the square as the government demanded. Wu'er Kaixi ordered an evacuation and was subsequently dismissed as chair of the students' federation. The radical student leader Chai Ling and others, mostly students who had traveled to Beijing for the protests, insisted on staying. Many students from Beijing returned to their campuses, but students from other provinces continued to throng into Tiananmen Square, and the situation became anarchic and chaotic. ${ }^{95}$ In addition, while the Chinese dissidents and students did have some external support — especially from Hong Kong and the United States — it was by no means comparable to what the East Germans could rely on. For all these reasons and more, the CCP survived the crisis, but SED did not.

In contrast to the Chinese protests, the East German protests attracted people from all walks of life — including the working class — and had a broad base of popular support. The reason why Leipzig, rather than East Berlin, became the beacon in fall 1989 was partly due to the fact that a coalition had formed between the protesters, who had been denied visas, and opposition groups in Leipzig. The roots of the opposition movement also included civil institutions such as the Protestant Church in East Germany; in Leipzig, the prayer services at the Nikolaikirche gave rise to the Monday demonstrations. Such institutions were lacking in China, and the CCP had long stymied the formation of an organized opposition. Some scholars, including Sullivan, have argued that the spring of 
1989 witnessed the emergence of a civil society in urban China, ${ }^{96}$ but that the movement was crushed too soon, because the alliance proved too weak and vulnerable.

Third, the protestors and supporters in Beijing and Leipzig differed in their expectations of how soldiers should behave during confrontations, as well as in terms of their own attitudes toward the use of violence. Before June 3, demonstrators in Beijing had experienced little violence at the hands of police or the military, notably less than what the demonstrators in East Germany had encountered before October 9. While the demonstrators in Leipzig, up until the end, fully believed that the troops were prepared to shoot, students and Beijing residents did not believe the PLA would actually open fire on them during the night of June 3-4. When Beijing residents came out to block the entry of the army and barricaded the intersections, however, a fierce struggle broke out and both sides became very emotional and violent. Civilians as well as army personnel were among the victims. The deaths and injuries suffered by PLA members, some of whom were killed by friendly fire, ${ }^{97}$ agitated other soldiers who responded by cruelly firing into the crowd. Sharon Erickson Nepstad points out some reasons for the tragic ending:

First, [the government] brought in tens of thousands of outside troops who had not been subject to appeals over the previous weeks of protests. Second, the CCP allegedly prompted hostile actions among citizen supporters. This, coupled with the movement's lack of ability to maintain nonviolent discipline, meant that it was easier for troops to justify the use of repression. ${ }^{98}$ 
Beijing citizens did not restrain themselves from violence. ${ }^{99}$ The government did not expect that the troops would meet such strong resistance that night and was apparently stunned by the death toll.

In contrast, East German citizens adhered to nonviolence throughout their protests on October 9, which proved critical in ensuring a peaceful outcome. Interestingly, Christoph Nonn points out that just during the previous Monday demonstration on October 2, both the police and the protestors - especially the young core members of the movement—resorted to violence, resulting in ten policemen being injured. In light of such experiences, organizers of the peace prayers repeatedly called for nonviolence the following week. On October 9, civil rights groups distributed thousands of pamphlets in front of churches calling for peaceful demonstrations. The slogan "Keine Gewalt" was chanted throughout the demonstration, and served as a mantra to warn security forces, as well as a means of disciplining the participants themselves. ${ }^{100}$ Moreover, in contrast to party elites, the party base had already realized before October 9 that violent suppression was not the means to solving the political problems of the GDR. ${ }^{101}$

Both the Chinese government and the SED planned to use force as their last resort, and without the precedent of Tiananmen, Leipzig may very well have witnessed a slaughter. Timothy Brook incisively points out the way in which Tiananmen disabled the "Chinese solution" for Eastern Europe:

The PLA brought the Democracy Movement to an end in China, but in Eastern Europe, where six Communist regimes would collapse in the next six months, the Beijing Massacre produced its opposite effect. None of these regimes was able to 
rescue itself by invoking "the China solution," as Eastern Europeans called the military suppression of democracy activists. Implemented once in Beijing, the China solution became unworkable among East European leaders. Only Nikolai Ceaucescu dared order his troops to fire on the Romanian people that winter, and his bid to save his regime failed. ${ }^{102}$

The impact of Tiananmen on the Wende is indirectly shown in the way that it helped galvanize East German protesters and helped them commit to nonviolence. Tiananmen served as a tangible recent example of a brutal crackdown that the East Germans were anxious not to repeat.

\section{Conclusion}

The Chinese prodemocracy movement and German reunification are complex events that unfolded in separate spheres. Nevertheless, events in Beijing provided East German officials with a contemporary parallel in a Communist nation as they developed a policy for dealing with prodemocracy demonstrators at home. Thus, the GDR's response to the Monday demonstrations in Leipzig in 1989 cannot be considered in isolation from the military crackdown earlier that year in China. Although the demonstrations in Beijing ended in bloodshed, I argue that the spirit of the Chinese student movement spurred people in East Germany and other Eastern European countries to fight for political reforms and democracy. The SED's response to Tiananmen alienated its own citizens from their government. The fear of a "Chinese solution" was real among ordinary East German citizens and provided an additional impetus for exodus and resistance. 
Tiananmen, in the end, constituted a counterexample and admonition for East German leaders. What happened in Beijing became a prelude to German reunification and the downfall of the European Communist regimes.

${ }^{1}$ Werner Meißner, ed., Die DDR und China (Berlin: Akademie, 1995), 17; James Miles, The Legacy of Tiananmen: China in Disarray (Ann Arbor: University of Michigan Press, 1996), 47, 50.

${ }^{2}$ Miles, Legacy, 45.

${ }^{3}$ Günter Jordan and Ralf Schenk, eds., Schwarzweiß und Farbe: DEFADokumentarfilme 1946-1990 (Berlin: Jovis, 1996), 232; Christoph Wielepp, “Montags abends in Leipzig," in DDR — Ein Staat vergeht, ed. Thomas Blanke and Rainer Erd (Frankfurt am Main: Fischer, 1990), 73.

${ }^{4}$ Timothy Brook, Quelling the People: The Military Suppression of the Beijing Democracy Movement (New York: Oxford University Press, 1992), 14; Tobias Hollitzer, “Der friedliche Verlauf des 9. Oktober 1989 in Leipzig," in Revolution und Transformation in der DDR 1989/1990, ed. Günther Heydemann et al. (Berlin: Duncker, 1999), 247-288, here $247 \mathrm{n} 2$.

${ }^{5}$ Peter Przybylski, Tatort Politbüro, 2 vols. (Berlin: Rowohlt, 1991-1992), 2:117$118 ; 120 ; 123$.

${ }^{6}$ Ying-shih Yu, "Student Movements in Chinese History and the Future of Democracy in China," in Culture and Politics in China: An Anatomy of Tiananmen Square, ed. Peter Li, Marjorie H. Li, and Steven Mark (New Brunswick, NJ: Transaction, 
1991), 257.

${ }^{7} \mathrm{Yu}$, "Student Movements," 247.

${ }^{8}$ Tony Saich, ed., The Chinese People's Movement: Perspectives on Spring 1989 (Armonk, NY: Sharpe, 1990); Jonathan D. Spence, The Search for Modern China, 3rd ed. (New York: Norton, 2013), 639-665; Gate of Heavenly Peace, dir. Carma Hinton (ITVS: 1996), Frontline documentary.

${ }^{9}$ Aktuelle Kamera, April 20, 1989, Deutsches Rundfunkarchiv, Potsdam (archival material). All translations are mine.

${ }^{10}$ Aktuelle Kamera, April 21, 1989, Deutsches Rundfunkarchiv, Potsdam.

${ }^{11}$ The three newspapers are accessible at http://zefys.staatsbibliothekberlin.de/ddr-presse/.

12 “Dann löst sich China auf,” Der Spiegel, May 22, 1989; Bernard M.

Gwertzman and Michael T. Kaufman, The Collapse of Communism (New York: Times, 1991), 51. This book is a compilation of reports in the New York Times.

${ }^{13}$ Mikhail Gorbachev, Memoirs (London: Bantam, 1997), 635-636.

${ }^{14} \mathrm{Yi} \mathrm{Mu}$ and Mark V. Thompson, Crisis at Tiananmen: Reform and Reality in Modern China (San Francisco: China Books \& Periodicals, 1989), 52-53.

${ }^{15}$ Gwertzman, Collapse, 55-56.

${ }^{16}$ Gwertzman, Collapse, 56; "Dann löst sich China auf."

${ }^{17}$ David Childs, The Two Red Flags: European Social Democracy and Soviet Communism since 1945 (London: Routledge, 2002), 119.

${ }^{18}$ Egon Krenz, Wenn Mauern fallen. Die friedliche Revolution (Wien: Neff, 
1990), 96; Walter Süß, Staatssicherheit am Ende. Warum es den Mächtigen nicht gelang, 1989 eine Revolution zu verhindern (Berlin: Ch. Links, 1999), 296-300.

${ }^{19}$ Gorbachev, Memoirs, 633.

${ }^{20}$ Elizabeth J. Perry, “Casting a Chinese 'Democracy' Movement,” in Popular Protest \& Political Culture in Modern China: Learning from 1989, ed. Jeffrey N.

Wasserstrom and Elizabeth J. Perry (Boulder, CO: Westview, 1994), 74-92, here 78;

June Four: A Chronicle of the Chinese Democratic Uprising (Fayetteville: University of Arkansas Press, 1989), 39-150; Frank Niming, "Learning How to Protest," in Chinese People's Movement, 83-105, here 95-101.

${ }^{21}$ Seth Faison, "The Changing Role of the Media," in Chinese People's Movement, 145-163.

22 “Chinesischer Ministerpräsident,” Neues Deutschland, May 20, 1989.

23 "Dann löst sich China auf."

${ }^{24}$ Otto Mann, “Leben in Peking," Neues Deutschland, May 24, 1989.

${ }^{25}$ Gorbachev, Memoirs, 636.

26 “Sprecher des Staatsrates," Neues Deutschland, June 7, 1989.

${ }^{27}$ Brook, Quelling, 161-162, 169. On the crucial point of the number of the dead, Dingxin Zhao's book Power of Tiananmen (Chicago: University of Chicago Press, 2001) misleads his readers by citing Brook only partially; compare Zhao (204n171) with Brook (161-162).

${ }^{28}$ Gwertzman, Collapse, 218.

29 “Erklärung von Krenz,” Neues Deutschland, June 9, 1989. 
30 “Erklärung der Volkskammer,” Neues Deutschland, June 9, 1989. Shortly before reunification, the first democratically elected Volkskammer revoked the legislature's previous support for the repression (see Meißner, DDR und China, 20). Today, at the DDR Museum in Berlin, an interactive exhibit cites this as one of the few occasions on which the pseudo-democratic Volkskammer voted unanimously.

31 “BRD. Bonn. 16. Juni 1989," Beziehung BRD—VR China, PA (Political Archives of the German Foreign Ministry), ZR 529/03.

${ }^{32}$ Süß, Staatssicherheit, 128-129.

${ }^{33}$ Timothy Garton Ash, "The Year of Truth," in The Revolutions of 1989, ed. Vladimir Tismaneanu (London: Routledge, 1999), 108-124, here 114.

${ }^{34}$ Miles, Legacy, 44.

${ }^{35}$ For example, “SED-Delegation in Peking,” Neues Deutschland, July 3, 1989;

"Yao Yilin empfing," Neues Deutschland, July 13, 1989; "Generalsekretär der KP Chinas empfing," Neues Deutschland, July 15, 1989; "Beziehungen der Freundschaft," Neues Deutschland, August 5, 1989.

${ }^{36}$ Karsten Timmer, Vom Aufbruch zum Umbruch: Die Bürgerbewegung in der DDR 1989 (Göttingen: Vandenhoeck \& Ruprecht, 2000), 106.

${ }^{37}$ Laurence H. McFalls, Communism's Collapse, Democracy's Demise? (New York: New York University Press, 1995), 48.

${ }^{38}$ Wielepp, “Montags," 73-74.

${ }^{39}$ Christian Joppke, "Why Leipzig? 'Exit' and 'Voice' in the East German Republic," German Politics 2, no. 3 (1993): 393-414, here 406-407. 
40 “Pekings Tiananmen-Platz," Neues Deutschland, October 2, 1989.

41 “Egon Krenz, Ministerbüro, Berlin, 2. Okt. 1989,” PA, ZR 2496/90.

${ }^{42}$ Hollitzer, "friedliche Verlauf,” 255 and 271; see, e.g., “Generalsekretär des ZK der KP Chinas empfing,” Neues Deutschland, September 27, 1989.

43،"Erich Honecker empfing," Neues Deutschland, October 10, 1989; Miles, Legacy, 45.

44 Timmer, Aufbruch, 189; Christoph Nonn, “Leipzig, 9. Oktober 1989: Ein Massaker findet nicht statt," in Eine andere deutsche Geschichte 1517-2017: Was wäre wenn. . (Paderborn: \Schöningh, 2017), 240-298, here 248.

45 "Befehl 8/89 des Vorsitzenden des Nationalen Verteidigungsrates” (September 26, 1989), in Przybylski, Politbüro, 2:117-118 and 2:367-369; Süß, Staatssicherheit, 240.

${ }^{46}$ Hollitzer, "friedliche Verlauf," 254.

47 Timmer, Aufbruch, 176.

${ }^{48}$ Wielepp, “Montags,” 75; Joppke, “Why Leipzig?” 407; Hollitzer, “friedliche Verlauf," 259; Süß, Staatssicherheit, 245.

${ }^{49}$ Przybylski, Politbüro, 120; Süß, Staatssicherheit, 280.

${ }^{50}$ Daniel V. Friedheim, "Regime Collapse in the Peaceful East German Revolution: The Role of Middle-Level Officials," German Politics 2, no. 1 (1993): 97112, here 102 . 
51 "Staatsfeindlichkeit nicht länger dulden," Leipziger Volkszeitung, October 6, 1989; cited in Wielepp, "Montags," 75; Friedheim, "Regime," 102n11; Joppke, "Why Leipzig?” 408; Hollitzer, “friedliche Verlauf,” 257; Süß, Staatssicherheit, 305.

${ }^{52}$ Wielepp, "Montags," 75; see also Albrecht Döhnert and Paulus Rummel, "Die Leipziger Montagsdemonstrationen," in Leipzig im Oktober, ed. Wolf-Jürgen Grabner et al. (Berlin: Wichern, 1990), 153.

${ }^{53}$ Timmer, Aufbruch, 180

${ }^{54}$ Timmer, Aufbruch, 177. According to Przybylski, 1551 people were arrested in the entire republic (Politbüro, 121); also see Süß, Staatssicherheit, 279-296.

${ }^{55}$ Hollitzer, "friedliche Verlauf," 268; Timmer, Aufbruch, 178.

${ }^{56}$ Hollitzer, “friedliche Verlauf," 273; Joppke, "Why Leipzig?” 408; Timmer, Aufbruch, 177.

${ }^{57}$ Friedheim, "Regime," 102n11.

${ }^{58}$ Joppke, “Why Leipzig?” 408; Timmer, Aufbruch, 179-182.

59 “Prayer Services Opened Door for Peaceful Street Protests," Wall Street

Journal, October 22, 2009, https://www.wsj.com/articles/SB125616146008699837;

“Krenz macht keinen Lenz,” Der Spiegel, October 30, 1989.

${ }^{60}$ Childs, Two Red Flags, 118, 119.

${ }^{61}$ McFalls, Communism's Collapse, 72.

${ }^{62}$ Nonn, "Massaker," 247.

${ }^{63}$ Timmer, Aufbruch, 189; Nonn, "Massaker," 247.

${ }^{64}$ Süß, Staatssicherheit, 301; Nonn, "Massaker,” 247. 
${ }^{65}$ Hollitzer, "friedliche Verlauf," 268-280; Süß, Staatssicherheit, 301-314.

${ }^{66}$ Timmer, Aufbruch, 184.

${ }^{67}$ Döhnert and Rummel, "Leipziger Montagsdemonstrationen," 77.

${ }^{68}$ Michael Hofmann and Dieter Rink, “Der Leipziger Aufbruch 1989: Zur

Genesis einer Heldenstadt," in Leipzig im Oktober, 114-122.

${ }^{69}$ Wielepp, "Montags," 77.

${ }^{70}$ Nonn, "Massaker," 248.

${ }^{71}$ Friedheim, "Regime,"103; see Krenz, Mauern, 204-205.

${ }^{72}$ Friedheim, "Regime," 105.

${ }^{73}$ Timmer, Aufbruch, 185-186.

${ }^{74}$ Hollitzer, "friedliche Verlauf," 282.

${ }^{75}$ Przybylski, Politbüro, 130.

${ }^{76}$ Gwertzman, Collapse, 173.

${ }^{77}$ Reinhold Andert and Wolfgang Herzberg, Der Sturz: Erich Honecker im Kreuzverhör (Berlin: Aufbau, 1990), 94-99.

${ }^{78}$ Miles, Legacy, 41-52.

${ }^{79}$ Miles, Legacy, 45.

${ }^{80}$ Gwertzman, Collapse, 196.

${ }^{81}$ Zhao Ziyang, Prisoner of the State (New York: Simon \& Schuster, 2009), 53.

${ }^{82}$ Tony Saich, "Discos and Dictatorship: Party-State and Society Relations in the People's Republic of China," in Popular Protest, 246-267, here 247.

${ }^{83}$ Miles, Legacy, 66-67. 
${ }^{84}$ Zhao, Power of Tiananmen, 235.

${ }^{85}$ Esherick and Wasserstrom, “Acting out Democracy," in Popular Protest, 32 69, here 57; Perry, “Casting,” 75.

${ }^{86}$ Daniel Chirot, "What Happened in Eastern Europe in 1989?" in Popular Protest, 218-245, here 229.

${ }^{87}$ McFalls, Communism's Collapse, 54-55.

${ }^{88}$ Jeffery N. Wasserstrom, "Student Protests and Chinese Tradition," in Chinese People's Movement, 3-24.

${ }^{89}$ Perry, "Casting," 80.

${ }^{90}$ Lawrence R. Sullivan, "The Emergence of Civil Society in China, Spring 1989," in Chinese People's Movement, 126-144.

${ }^{91}$ Saich, "When Worlds Collide," in Chinese People's Movement, 25-49, here 37.

Craig C. Calhoun discusses the limitations of arguments about student elitism in "Science, Democracy, and the Politics of Identity," in Popular Protest, 93-124.

${ }^{92}$ Niming, "Learning."

${ }^{93}$ Perry, “Casting,” 91n69; “China,” Neues Deutschland, June 12, 1989;

“Todesurteile," Neues Deutschland, June 22, 1989; “Todesurteile," Neues Deutschland, June 23, 1989.

${ }^{94}$ Zhao, Power of Tiananmen, 190-195; Esherick and Wasserstrom, "Acting,” 35.

${ }^{95}$ Lee Feigon, "Gender and the Chinese Student Movement," in Popular Protest, 125-135, here 131; Woei Lien Chong, "Petitioners, Popperians, and Hunger Strikers," in 
Chinese People's Movement, 106-125, here 121-122; Gate of Heavenly Peace, documentary.

${ }^{96}$ Sullivan, "Emergence."

${ }^{97}$ Brook, Quelling, 187.

${ }^{98}$ Sharon Erickson Nepstad, Nonviolent Revolutions: Civil Resistance in the Late 20th Century (Oxford: Oxford University Press, 2011), 37.

${ }^{99}$ Andrew Scobell, "Why the People's Army Fired on the People," in Chinese Democracy and the Crisis of 1989: Chinese and American Reflections, ed. Roger V. Des Forges, Luo Ning, and Wu Yen-bo (Albany: State University of New York Press, 1993), $191-122 ; 197$.

${ }^{100}$ Nonn, "Massaker," 249-250.

${ }^{101}$ Nonn, "Massaker," 255.

${ }^{102}$ Brook, Quelling, 14. 